\title{
AN ASSESSMENT OF INFORMATION LITERACY COMPETENCE OF POSTGRADUATE STUDENTS
}

\author{
Sneha Joseph \\ Dept. of Library and Information Science, \\ St. Berchmans College (Autonomous) Changanassery, Kottayam, Kerala, India

\section{Deepa John} \\ Faculty, Dept. of Library and Information Science, \\ St. Berchmans College (Autonomous) Changanassery, Kottayam, Kerala, India \\ Supriya Susan Kurian \\ Librarian, Mar Thoma College for Women, \\ Perumbavoor, Ernakulam, Kerala, India

\section{Tinju Tom} \\ Faculty, Dept. of Library and Information Science, \\ St. Berchmans College (Autonomous) Changanassery, Kottayam, Kerala, India
}

\begin{abstract}
Information literacy is highly essential in this contemporary society due to rapid technological change and proliferation of information resources. To obtain authentic, valid and reliable information, one needs to be information literate. Information literacy is a skill for moving awareness about text-based learning to e-resource based learning. The present study is undertaken to find out the extent of information literacy skills of the P.G students of St. Thomas College, Palai in utilizing information resources. The study investigated the level of awareness of the $P G$ students about different sources of information and assessed the ability of P.G students to search, locate, retrieve and evaluate the information. The study also determines the impact of information literacy on use of library information services and the role of libraries in information literacy skills. Suggestions have been given for empowering the students with information literacy skills.
\end{abstract}

Key words: Information literacy, P.G students, Library.

Cite this Article: Sneha Joseph, Deepa John, Supriya Susan Kurian and Tinju Tom An Assessment of Information Literacy Competence of Postgraduate Students. International Journal of Library \& Information Science, 7(2), 2018, pp. 45-54. http://iaeme.com/Home/issue/IJLIS?Volume=7\&Issue=2 


\section{INTRODUCTION}

Information literacy is important for today's learners. The nature of information is changing the nature of the currency of democracy. Over a period of time the format of information has also changed owing to the advancement in ICT. Now more and more information is available online in digital format than in print. The quantum of information available online is putting users in a stressful situation as they are finding it difficult to choose the right information due to lack of search skills amongst the users. Information literacy is a skill for moving awareness about text-based learning to e-resource based learning. It promotes problem solving approaches and thinking skills - asking questions and seeking answers, finding information, forming opinions, evaluating sources and making decisions fostering successful learners, effective contributors, confident individuals and responsible citizens. Information literacy is the ability to recognize the need for information to solve problems and develop ideas; pose important questions; use a variety of information gathering strategies, locate relevant and appropriate information ; assess information for quality, authority, accuracy, and authenticity. It includes the abilities to use the practical and conceptual tools of information technology, to understand, form, format, location, and access methods. Information literacy means knowing how to find, evaluate and use information in all formats. It is more than print literacy, computer literacy or media literacy.

Post graduate education is education after the completion of a first degree. It involves learning and studying for academic or professional degrees. The organization and structure of post graduate education varies in different countries. Post graduate students of any university need to be information literate. They undertake research that affects change in the society. Their findings solve societal problems. Their research activities also lead to new inventions. It is therefore important for them to acquire information literacy skills.

\section{REVIEW OF LITERATURE}

Munavalli, Sanjay B., and B.D. Kumbar ${ }^{1}$ made a study on prescriptive/ diagnostic assessment of information literacy skills of science students at PCACS. The main aim of the study is to analyse the information literacy skills by UG science students of Pillai College of Arts, Commerce and Science, Maharashtra (PCACS). A questionnaire method was used to collect the data from the students. Study highlighted the importance of conducting IL programmes to upgrade the skills among students. The questions were very basic related to frequency of library visit, purpose of library visit, awareness and use of information resources and services. Demographic questions, mainly gender, were added in the questionnaire. The study reveals that $13(14.60 \%)$ responded somewhat agree to receive ILs. Majority of the respondents indicated library is fully automated. Highest number of students that is $79(88.76 \%)$ indicated they are aware and use internet service. About $76(85.39 \%)$ responded they are aware of OPAC/Web-OPAC service and $71(79.77 \%)$ indicated they used. Regarding online reservation or renewal $65(73.03 \%)$ students responded aware and $57(64.04 \%)$ used. Majority of the students are aware but less number of students is making use of ICT-based services.

Elnoor, Omer Salih, et.al. ${ }^{2}$ assessed of pre and final year undergraduate veterinary students information literacy competencies and attitude towards e-learning. The main aim of the study is to assess the information literacy competencies free and final year undergraduate veterinary students and their attitude towards e-learning. The 120 pre-final and final year veterinary students studying at Guru Angad Dev Veterinary and Animal Sciences University, Ludhiana were selected randomly and data was collected with the help of a structural questionnaire consisting of 25 items with respect to concept identification, search strategy, document types, search tools, use of result and e-learning. The study revealed that only $12.5 \%$ of the veterinary students belonged to high knowledge level category whereas majority of 
them possessed low knowledge towards information literacy competencies. A high percentage of veterinary students lacked the necessary knowledge and skills to identify main concept and significance of words $(52.5 \%)$, to opt appropriate search strategy $(83.1 \%)$, to select required document types $(42.1 \%)$, to utilize efficient search tools $(73.8 \%)$ and to evaluate and use results $(68.8 \%)$. Only few students had ability to use computer as experts. The study revealed that notable gaps among students towards information literacy competencies and e-learning, hence, teaching of credit bearing information literacy courses is imperative to enhance undergraduate veterinary student's knowledge and information seeking skills.

\section{OBJECTIVES}

- To know the level of awareness of the respondents about different sources of information.

- To determine the impact of information literacy on use of library information services

- To determine the role of libraries in improving information literacy skills.

- To assess the ability of P.G students to search, locate, retrieve and evaluate the information

- To offer suggestions for the effective strategies to be adopted for empowering the students with information literacy skills.

\section{METHODOLOGY}

A questionnaire was developed to ascertain information literacy knowledge and skill levels of Post Graduate Students of various departments of St. Thomas College, Palai. The questionnaire consisted of 20 items, with multiple choices and 'yes/no' questions. Questions 8, 17 and 19 were pairs, with the second question in each pair asking for an explanation to the previous question's answer. The questionnaire designed for this study is mainly focused on various aspects included in the objectives and are grouped and processed under 7 areas. The investigator visited the departments for taking response through the questionnaires. The investigator distributed 470 questionnaires to the departments during the month of March 2730, 2017. The filled questionnaires i.e., 450 numbers were received within one week of distribution. Thus the present study is based on the responses provided by 450 respondents.

\section{ANALYSIS OF DATA}

\subsection{Information Sources}

\subsubsection{Use and Availability of Sources}

Respondents were asked to indicate about their awareness, use and availability of sources in their library. 
Sneha Joseph, Deepa John, Supriya Susan Kurian and Tinju Tom

Table 1 Awareness, Use and Availability of Sources

\begin{tabular}{|c|c|c|c|c|c|}
\hline Sl. No. & \multicolumn{3}{|c|}{ Awareness } & \multicolumn{2}{c|}{ Use } \\
\hline & Sources & Yes & No & Yes & No \\
\hline 1 & Books & $450(100 \%)$ & 0 & $260(57.78 \%)$ & $190(42.22 \%)$ \\
\hline 2 & Journals & $150(33.33 \%)$ & $189(42 \%)$ & $210(46.67 \%)$ & $240(53.33 \%)$ \\
\hline 3 & Reference books & $430(95.56 \%)$ & $220(48.89 \%)$ & $335(74.44 \%)$ & $115(25.56 \%)$ \\
\hline 4 & Databases/e-resources & $132(29.33 \%)$ & $318(70.67 \%)$ & $240(53.33 \%)$ & $210(46.67 \%)$ \\
\hline 5 & Periodicals & $190(42.22 \%)$ & $60(13.33 \%)$ & $320(71.11 \%)$ & $130(28.89 \%)$ \\
\hline 6 & Dissertation & $295(65.56 \%)$ & $155(34.44 \%)$ & $150(33.33 \%)$ & $300(66.67 \%)$ \\
\hline
\end{tabular}

\subsubsection{Awareness}

When all P.G students (100\%) are aware of books, 95.56\% of P.G students are aware of reference books followed by $65.56 \%$ are aware of dissertation, $42.22 \%$ of P.G students are aware of periodicals, $33.33 \%$ are aware of journals and $29.33 \%$ are aware of databases/eresources.

\subsubsection{Use}

$74.44 \%$ of P.G students use reference books followed by $71.11 \%$ of P.G students use periodicals, $57.78 \%$ use books, $53.33 \%$ use databases, $46.67 \%$ use journals and $33.33 \%$ of P.G students use dissertation.

\subsection{Ranking of Sources}

Students were asked to rank the sources they prefer according to their order of priority.

Table 2 Ranking of sources

\begin{tabular}{|c|c|c|c|c|c|c|c|}
\hline \multirow{2}{*}{$\begin{array}{c}\text { Sl. } \\
\text { No. }\end{array}$} & \multirow{2}{*}{ Sources } & \multicolumn{6}{|c|}{ Grade of Preference } \\
\cline { 3 - 8 } & $\mathbf{1}$ & $\mathbf{2}$ & $\mathbf{3}$ & $\mathbf{4}$ & $\mathbf{5}$ & $\mathbf{6}$ \\
\cline { 3 - 8 } & \multicolumn{6}{|c|}{ No. of Respondents \& Percentage } \\
\hline 1 & Books & $\begin{array}{c}397 \\
(88.22 \%)\end{array}$ & $31(6.89 \%)$ & $20(4.44 \%)$ & 0 & 0 & 0 \\
\hline 2 & Journals & $117(26 \%)$ & $\begin{array}{c}91 \\
(20.22 \%)\end{array}$ & $\begin{array}{c}201 \\
(44.67 \%)\end{array}$ & $18(4 \%)$ & $12(2.67 \%)$ & $9(2 \%)$ \\
\hline 3 & Reference books & $\begin{array}{c}137 \\
(30.44 \%)\end{array}$ & $\begin{array}{c}211 \\
(46.89 \%)\end{array}$ & $75(16.67 \%)$ & $10(2.22 \%)$ & $9(2 \%)$ & $6(1.33 \%)$ \\
\hline 4 & $\begin{array}{c}\text { Databases/e- } \\
\text { resources }\end{array}$ & $8(1.78 \%)$ & $17(3.78 \%)$ & $70(15.56 \%)$ & $\begin{array}{c}209 \\
(46.44 \%)\end{array}$ & $124(27.56 \%)$ & $22(4.89 \%)$ \\
\hline 5 & Periodicals & $7(1.56 \%)$ & $5(1.11 \%)$ & $28(6.22 \%)$ & $\begin{array}{c}186 \\
(41.33 \%)\end{array}$ & $190(42.22 \%)$ & $34(7.56 \%)$ \\
\hline 6 & Dissertation & $6(1.33 \%)$ & $8(1.78 \%)$ & $13(2.89 \%)$ & $28(6.22 \%)$ & $172(41.33 \%)$ & $223(49.56 \%)$ \\
\hline
\end{tabular}

\subsubsection{First Preference}

When $88.22 \%$ of P.G students gave first preference for books, $30.44 \%$ for reference books followed by $26 \%$ for journals, $1.78 \%$ for databases/e- resources, $1.56 \%$ for periodicals and $1.33 \%$ of P.G students gave first preference for dissertation. 


\subsubsection{Second Preference}

When $46.89 \%$ of P.G students gave second preference for reference books, $20.22 \%$ for journals followed by $6.89 \%$ of students for books, $3.78 \%$ for database/e-resources, $1.78 \%$ for dissertation and only $1.11 \%$ of P.G students gave second preference for periodicals.

\subsubsection{Third Preference}

When $44.67 \%$ of P.G students gave third preference for journals, $16.67 \%$ of students for reference books, followed by $15.56 \%$ for database/e-resources, $6.22 \%$ of students for periodicals and $4.44 \%$ for books and only $2.89 \%$ of P.G students gave third preference for dissertation.

\subsection{Information Services}

\subsubsection{Awareness, Use, Availability of Services}

Respondents were asked to indicate their awareness, use and availability of services provided in their library

Table 3 Awareness, Use and Availability of Services

\begin{tabular}{|c|c|c|c|c|c|c|c|}
\hline \multirow{2}{*}{ Sl. No. } & \multicolumn{3}{|c|}{ Awareness } & \multicolumn{2}{c|}{ Use } & \multicolumn{2}{c|}{ Availability } \\
\cline { 2 - 7 } & Services & Yes & No & Yes & No & Yes & No \\
\hline 1 & Circulation & $\begin{array}{c}430 \\
(95.56 \%)\end{array}$ & $20(4.44 \%)$ & $\begin{array}{c}310 \\
(68.89 \%)\end{array}$ & $\begin{array}{c}140 \\
(31.11 \%)\end{array}$ & $450(100 \%)$ & 0 \\
\hline 2 & Reference & $\begin{array}{c}110 \\
(24.44 \%)\end{array}$ & $\begin{array}{c}340 \\
(75.56 \%)\end{array}$ & $396(88 \%)$ & $54(12 \%)$ & $394(87.56 \%)$ & $56(12.44 \%)$ \\
\hline 3 & $\begin{array}{c}\text { Reprographic/ } \\
\text { Photostat }\end{array}$ & $\begin{array}{c}420 \\
(93.33 \%)\end{array}$ & $30(6.67 \%)$ & $\begin{array}{c}440 \\
(97.78 \%)\end{array}$ & $30(6.67 \%)$ & $450(100 \%)$ & 0 \\
\hline 4 & Internet & $\begin{array}{c}445 \\
(98.89 \%)\end{array}$ & $5(1.11 \%)$ & $\begin{array}{c}445 \\
(98.89 \%)\end{array}$ & $5(1.11 \%)$ & $445(98.89 \%)$ & $5(1.11 \%)$ \\
\hline 5 & $\begin{array}{c}\text { Current Awareness } \\
\text { Services }\end{array}$ & 0 & $\begin{array}{c}390 \\
(86.67 \%)\end{array}$ & 0 & $\begin{array}{c}310 \\
(68.89 \%)\end{array}$ & $61(13.56 \%)$ & $389(86.44 \%)$ \\
\hline 6 & Subject Gateways & 0 & $\begin{array}{c}425 \\
(94.44 \%)\end{array}$ & $49(10.89 \%)$ & $\begin{array}{c}401 \\
(89.11 \%)\end{array}$ & $25(5.56 \%)$ & $425(94.44 \%)$ \\
\hline 7 & OPAC & $40(8.89 \%)$ & $\begin{array}{c}410 \\
(91.1 \%)\end{array}$ & $\begin{array}{c}156 \\
(34.67 \%)\end{array}$ & $\begin{array}{c}294 \\
(65.33 \%)\end{array}$ & $450(100 \%)$ & 0 \\
\hline
\end{tabular}

\subsubsection{Awareness}

When $98.89 \%$ of P.G students are aware of internet, $95.56 \%$ are aware of circulation followed by $93.33 \%$ are aware of reprographic, $24.44 \%$ are aware of reference and $8.89 \%$ are aware of OPAC.

\subsubsection{Use}

When $98.89 \%$ of P.G students use internet, $97.78 \%$ of P.G students use reprographic followed by $88 \%$ use reference, $68.89 \%$ use circulation, $34.67 \%$ use OPAC and $10.89 \%$ use subject gateways. 


\subsubsection{Availability}

When all P.G students (100\%) stated that circulation, reference, reprographic and OPAC are available in their library, $98.89 \%$ stated that Internet are available in their library followed by $13.56 \%$ of P.G students stated that current awareness services are available in their library and $5.56 \%$ stated that subject gateways are available.

\subsection{Level of Information Literacy}

Table 4 Level of Information Literacy

\begin{tabular}{|c|c|c|c|}
\hline SI. No & $\begin{array}{c}\text { Level of Information } \\
\text { Searching }\end{array}$ & No. of respondents & Percentage \\
\hline 1 & Excellent & 3 & $5.45 \%$ \\
\hline 2 & Very good & 6 & $10.90 \%$ \\
\hline 3 & Good & 46 & $83.63 \%$ \\
\hline
\end{tabular}

Table 4 shows that when $83.63 \%$ of P.G students are good in Information literacy, $10.90 \%$ are very good and $5.45 \%$ are excellent

\subsection{Provision of Information Literacy Programmes}

A question was asked to know whether their library is providing information literacy programmes.

Table 5 Provision of Information Literacy Programmes

\begin{tabular}{|c|c|c|}
\hline Parameter & No. of Respondents & Percentage \\
\hline Yes & 140 & $31.11 \%$ \\
\hline No & 233 & $51.78 \%$ \\
\hline Don't Know & 75 & $16.67 \%$ \\
\hline
\end{tabular}

Table 5 shows that $51.78 \%$ of P.G students stated that library is not providing

Information Literacy Programmes, $31.11 \%$ of respondents stated that the library is providing

Information Literacy Programmes for proper utilization of information, and $16.67 \%$ students

stated that they don't know about Information Literacy Programmes.

\subsection{Source to become Information Literate}

Students were asked to rank the source which helped them to be information literate. 
An Assessment of Information Literacy Competence of Postgraduate Students

Table 6 Source to become Information Literate

\begin{tabular}{|c|c|c|c|c|c|c|}
\hline \multirow{2}{*}{ SI. No. } & \multirow{2}{*}{ Sources } & \multicolumn{5}{|c|}{ Rank } \\
\cline { 3 - 7 } & $\mathbf{1}$ & $\mathbf{2}$ & $\mathbf{3}$ & $\mathbf{4}$ & $\mathbf{5}$ \\
\cline { 3 - 7 } & \multicolumn{5}{|c|}{ No. of Respondents \& Percentage } \\
\hline 1 & $\begin{array}{c}\text { Librarian/Library } \\
\text { orientation }\end{array}$ & $40(8.89 \%)$ & $60(13.33 \%)$ & $30(6.67 \%$ & $\begin{array}{c}120 \\
(26.67 \%)\end{array}$ & $198(44 \%)$ \\
\hline 2 & $\begin{array}{c}\text { From seminars, } \\
\text { workshop }\end{array}$ & $16(3.56 \%)$ & $94(20.89 \%)$ & $\begin{array}{c}105 \\
(23.33 \%)\end{array}$ & $\begin{array}{c}178 \\
(39.56 \%)\end{array}$ & $55(12.22 \%)$ \\
\hline 3 & Friends & $\begin{array}{c}260 \\
(57.78 \%)\end{array}$ & $\begin{array}{c}103 \\
(22.89 \%)\end{array}$ & $45(10 \%)$ & $35(7.78 \%)$ & $5(1.11 \%)$ \\
\hline 4 & Internet & $88(19.56 \%)$ & $\begin{array}{c}200 \\
(44.44 \%)\end{array}$ & $\begin{array}{c}112 \\
(24.89 \%)\end{array}$ & $47(10.44 \%)$ & 0 \\
\hline 5 & Teacher & 0 & $80(17.78 \%)$ & $97(21.56 \%)$ & 113 & 158 \\
$(25.11 \%)$ & $(35.11 \%)$ \\
\hline
\end{tabular}

\subsubsection{First Rank}

It is clear from the analysis of table 6 that $57.78 \%$ students ranked friends as the source that helped them to become information literate, $19.56 \%$ ranked internet, followed by $8.89 \%$ ranked librarian/library orientation and only $3.56 \%$ ranked seminars and workshops.

\subsubsection{Second Rank}

When $44.44 \%$ of P.G students ranked internet, $22.89 \%$ ranked friends, $20.89 \%$ ranked seminars, workshops, $17.78 \%$ ranked teacher and $13.33 \%$ ranked librarian/library orientation as the source that helped them to be literate.

\subsubsection{Third Rank}

When $24.89 \%$ of P.G students ranked internet, $23.33 \%$ ranked seminars, workshops, $21.56 \%$ ranked teacher, $6.67 \%$ ranked librarian/library orientation and $10 \%$ ranked friends as the source that helped them to be literate.

\subsection{Additional Information Literacy Programme}

A question was asked to those who are not satisfied with their information literacy programme to suggest the aspect to be included to improve Information Literacy Programmes.

Table 7 Additional Information Literacy Program

\begin{tabular}{|c|c|c|}
\hline Suggestions & No. of Respondents & Percentage \\
\hline Accessing library sources & 64 & $14.22 \%$ \\
\hline Catalogue search OPAC & 53 & $11.78 \%$ \\
\hline Library website use & 112 & $24.89 \%$ \\
\hline E-resource access & 123 & $27.33 \%$ \\
\hline Database access & 226 & $50.22 \%$ \\
\hline New technologies & 241 & $53.56 \%$ \\
\hline $\begin{array}{c}\text { Evaluation of Information } \\
\text { sources }\end{array}$ & 280 & $62.22 \%$ \\
\hline Search strategies & 173 & $38.44 \%$ \\
\hline
\end{tabular}

It is evident from the analysis of Table 7 that multiple responses were received. The analysis shows that P.G students suggested to include the programmes such as evaluation 
information $(62.22 \%)$, followed by $53.56 \%$ New technologies, $50.22 \%$ database access, $38.44 \%$ search strategies, $27.33 \%$ e-resource access, $24.89 \%$ library website, $14.73 \%$ catalogue search OPAC, $14.22 \%$ accessing library sources to improve information literacy programmes.

\subsection{Awareness and Use of Open Access Resources}

Respondents were asked to indicate about their awareness and use of open access resources.

Table 8 Awareness and Use of Open Access Resources

\begin{tabular}{|c|c|c|c|c|c|}
\hline \multirow{2}{*}{ S1. No. } & \multicolumn{2}{|c|}{ Awareness } & \multicolumn{2}{c|}{ Use } \\
\cline { 2 - 6 } & Open Access Resources & Yes & No & Yes & No \\
\hline 1 & DOAJ & $30(6.67 \%)$ & $420(93.33 \%)$ & 0 & $450(100 \%)$ \\
\hline 2 & DOAR & $20(4.44 \%)$ & $430(95.56 \%)$ & 0 & $450(100 \%)$ \\
\hline
\end{tabular}

\subsubsection{Awareness}

When $95.56 \%$ of P.G students are not aware of DOAR $93.33 \%$ of P.G students are not aware of DOAJ.

\subsubsection{Use}

Nobody use open access resources like DOAJ, DOAR.

\subsection{Evaluation Criteria}

A question was asked to know the different criteria they use for evaluating information.

Table 9 Criteria for Evaluating Information

\begin{tabular}{|c|c|c|c|}
\hline Sl. No & Evaluation criteria & Yes & No \\
\hline 1 & Currency & $22(4.89 \%)$ & $298(66.22 \%)$ \\
\hline 2 & Relevancy & $22(4.89 \%)$ & $340(75.56 \%)$ \\
\hline 3 & Accuracy & $56(12.44 \%)$ & $120(26.67 \%)$ \\
\hline 4 & Authenticity & $16(3.56 \%)$ & $267(59.33 \%)$ \\
\hline 5 & Validity & $19(4.22 \%)$ & $286(63.56 \%)$ \\
\hline 6 & Authority of Author & $34(7.56 \%)$ & $164(36.44 \%)$ \\
\hline 7 & No criteria & $330(73.33 \%)$ & $164(36.44 \%)$ \\
\hline
\end{tabular}

Table 9 indicates that majority of the P.G students doesn't use many of the evaluation criteria. The analysis of the table shows that $75.56 \%$ doesn't use the criteria relevancy followed by $66.22 \%$ doesn't use the criteria currency, $63.56 \%$ doesn't use the criteria validity, where as $59.33 \%$ doesn't use authenticity, followed by $36.44 \%$ doesn't use authority of author criteria, $26.67 \%$ of P.G students doesn't use the evaluation criteria accuracy and it also reveals that $63.56 \%$ of P.G students use absolutely no criteria.

\section{MAJOR FINDINGS}

- It is evident from the analysis that majority of P.G students seek information for their academic purpose through internet and their friends. Only a few students consider library as a source for their academic information.

- It is evident from the analysis that books are the most preferred information source. Whereas databases/e-resources and journals are the least preferred. 
- It is evident from the analysis that information literacy programmes is insufficient hence P.G students suggested to include the aspects such as search strategies, accessing library sources, catalogue search OPAC, library website use, Internet search, e-resources access, database access, new technologies, evaluation of information Sources.

- It is evident from the analysis that majority of P.G students are unaware of open access resources such as DOAJ, DOAR etc and none of them are using these resources.

- The non-use of major options in OPAC facility shows their unawareness on advanced search techniques.

- Majority of P.G students believed that their friends and internet has helped them to become information literate. Whereas the role of librarian or library orientation is very minimal.

- Analysis reveals that majority of the students are not at all confident about their knowledge on searching information.

- It is evident from the analysis that majority of P.G students are not using any criteria to evaluate information. It is a great relief to know some of the students are evaluating information by using criteria such as accuracy, validity, authority of author, currency, relevancy, authenticity before using information.

\subsection{Suggestions}

- As it is evident from the findings that majority of P.G students do not consider library as the major source of information for their academic purpose, shows their information illiteracy which can be eliminated through effective information literacy programmes.

- It is suggested to give awareness on importance of current and reliable information sources such as journals, database/e-resources of their concerned field.

- It is suggested that library must make available information services such as CAS and Subject Gateways. Less use of OPAC shows the inefficiency of library orientation. In this context it is advised to give more importance to OPAC while giving library orientation.

- It is suggested to give detail information on aspects such as search strategies, accessing library sources, catalogue search OPAC, library website use, internet search, e-resources access, database access, new technologies, evaluation of information Sources etc as there are very important to make use of information effectively.

- Due to the availability of abundance of information, make students aware of authentic information by giving classes on evaluation criteria.

\section{CONCLUSION}

The present study is conducted to identify the level of information literacy of the post graduate students of St. Thomas College, Palai with a view to provide recommendations for planning and implementing the appropriate information programmes. The study reveals that majority of the PG students are unable to identify, locate, collect, evaluate and use the required information. An important point noted down is that, the PG students are not much aware about electronic information resources and their use. The study also revealed that an information literacy programme is inevitable for the students in the academic institutions to make more information literate. The library and information professional can do a lot to attain this goal. 


\section{REFERENCES}

[1] Munavalli, Sanjay B., and B.D. Kumbar. "Prescriptive/Diagnostic Assessment of Information Literacy Skills of Science Students at PCACS: A Pilot Study." PEARL - A Journal of Library and Information Science 11.1(2017):22-27.

[2] Elnoor, Omer Salih, et al. "Assessment of Postgraduate Veterinary Student's Information Literacy Competencies and Attitude Towards E-learning." Indian Journal of Economics and Development 13.2(2017):339-344. 